\title{
Prevalence Of Indirect Restoration on the Disto Occlusal Aspect of Posterior Teeth - An Institutional Based Retrospective Study
}

Research Article

\author{
Delphine Priscilla Antony ${ }^{1 *}$, Jaya keerthana $S^{2}$, Maragathavalli. $\mathrm{G}^{3}$
}

${ }^{1}$ Senior Lecturer, Department of Conservative Dentistry and Endodontics, Saveetha Dental College and Hospitals, Saveetha Institute of Medical and Technical Sciences(SIMATS), Saveetha University, Chennai 600 077, Tamil Nadu, India.

${ }^{2}$ Undergraduate Student, Saveetha Dental College and Hospitals, Saveetha Institute of Medical and Technical Sciences(SIMATS), Saveetha University, Chennai 600 077, Tamil Nadu, India.

${ }^{3}$ Professor, Department of oral Medicine and Radiology, Saveetha Dental College and Hospitals, Saveetha Institute of Medical and Technical Sciences(SIMATS), Saveetha University, Chennai 600 077, Tamil Nadu, India.

\section{Abstract}

\begin{abstract}
Ceramic in lays can be used as an aesthetic alternative to metal class I or II restorations. These restorations conserve tooth structure which has mechanical benefits of modern adhesive technology, which can strengthen the compromised tooth.Ceramic inlays offer a viable alternative to amalgam or cast-gold restorations, both of which have long histories of clinical success.Aim of the study is to evaluate the prevalence of patients who underwent indirect restoration on disto occlusal aspect. A total of 27 patients were taken into study who underwent indirect restoration on disto occlusal aspect from conservative dentistry and endodontics department, saveetha dental College, Chennai, India. The datas were collected from 86,000 patient reports who came for dental treatments from June 2019 to March 2020.The collected data's were then analysed in SPSS software.Out of 27 patients the most common age group was 26 to 40 years which is $51.8 \%$ and males were more common than females.chi square association test was done [Chi square value- 0.517 and $p$ value $-0.772(\mathrm{p}>0.05)]$. Within the limitations of the current study it was observed that there is no significance of age and gender of patients who underwent indirect restoration on disto occlusal aspect.
\end{abstract}

Keywords: Disto; Indirect; Occlusal; Patients; Restoration.

\section{Introduction}

In dentistry ceramic materials have been in use around since the late 18th century the possibilities for the use in the posterior region have never been as large as in present times, enabling ceramic restorations to be used as an alternative to many existing restorative techniques [1].

The application of ceramics in dentistry started with anterior and posterior restorations, but due to various reasons in early ceramic materials, The ceramics never gained great popularity. After the second world war, new developments allowed for porcelain to be fused to gold [2].

All ceramic based inlays provide aesthetics and durability as restoration. It maintains a better anatomic forms, exhibits a better marginal integrity, and colour stability in oral cavity. All Ceramicbased inlays also reinforce the remaining dental hard tissue as they bond to the tooth with adhesive cements [3].

Ceramic inlay restoration techniques are evolving problems with high failure rates repeatedly solved in the mid-80s with improved materials and the introduction of adhesive techniques [4].

At present many of the major companies in the dental business have their own system for designing and manufacturing ceramic restoration out of several different types of ceramics [5]. Recently the use of prefabricated ceramic inlays in combination with composite has been recommended to overcome the disadvantages of polymerisation shrinkage and poor proximal contact when using posterior composite [6-8]. Previously our team had conducted numerous clinical trials [9-15] and lab animal studies [16-20] and in vitro studies over the past 5 years [21-23].

\section{*Corresponding Author:}

Dr. Delphine Priscilla Antony. S,

Senior Lecturer, Department of Conservative Dentistry and Endodontics, Saveetha Dental College and Hospitals, Saveetha Institute of Medical and Technical Sciences(SIMATS), Saveetha University, Chennai 600 077, Tamil Nadu, India.

E-mail: delphine.sdc@saveetha.com

Received: August 03, 2019

Accepted: August 26, 2019

Published: August 30, 2019

Citation: Delphine Priscilla Antony, Jaya keerthana S, Maragathavalli G. Prevalence Of Indirect Restoration on the Disto Occlusal Aspect of Posterior Teeth - An Institutional Based Retrospective Study. Int J Dentistry Oral Sci. 2019;S2:02:007:24-27. doi: http://dx.doi.org/10.19070/2377-8075-SI02-02007

Copyright: Delphine Priscilla Antony. $\mathbf{S}^{\circ}$ 2019. This is an open-access article distributed under the terms of the Creative Commons Attribution License, which permits unrestricted use, distribution and reproduction in any medium, provided the original author and source are credited. 
Aim of this study is to evaluate the prevalence of patients who underwent indirect restoration on disto occlusal aspect.

\section{Materials and Methods}

\section{Study setting and sampling}

This study is a single-center retrospective study, carried out in the Conservative dentistry department in a private dental college. The present study was approved by the ethical board of the institution - Institutional ethical committee [IEC] (Ethical approval number: SDC/SIHEC/2020/DIASDATA/0619-0320) and was in accordance with the ethical standards that were stipulated. All available records of patients who underwent indirect restoration on disto occlusal aspect from June 2019 - April 2020, were examined and included in our data collection. A total of 27 case sheets were reviewed. Cross verification of data for error was done by presence of additional reviewers and by photographs evaluation. Two examiners were involved in the study.

\section{Data collection}

Acquisition of data was done from the hospital digital database which records all patient details. The collected data were grouped based on their age and gender. Gender was categorised into males and females, age was grouped into three groups 18 to 25 years, 26 to 40 years, 41 to 61 years. The data were entered in the system in a methodical manner. For this study, data on the number of patients underwent indirect restoration on disto occlusal aspec and clinical variables such as their age, gender were collected. The data was then entered in excel manually and imported to SPSS for analysis. Incomplete or censored data were excluded from the study.

\section{Statistical analysis}

The statistical analysis was done using SPSS software (SPSS version 21.0, SPSS, Chicago II, USA). Descriptive statistics were used to summarise the demographic information of the patients included in this study. Descriptive statistics is used for the acqui- sition of frequency distribution of the data. Association of age and gender with indirect restoration on disto occlusal aspect was analysed using a chi-square test. The $\mathrm{p}$ value of less than 0.05 was considered to be statistically significant.

\section{Results and Discussion}

Out of 27 patients the most common age group was 26 to 40 years which is $51.8 \%$ and males $81.4 \%$ were more common than females $18.5 \%$.

Figure 1 shows the comparison of the age and gender of patients who underwent indirect restoration on disto occlusal aspect.The most common age group was found to be between 26-40 years with $51.8 \%$ of patients with indirect restoration on disto occlusal aspect ,followed by $33.3 \%$ between the age group of 41 to 61 years $14.8 \%$ between the age group between 18 to 25 years underwent indirect restoration on disto occlusal aspect. Males $81.4 \%$ more commonly had indirect restoration on disto occlusal aspect than females $18.5 \%$.

Figure 2 shows the association of age and tooth number of patients who underwent indirect restoration on disto occlusal aspect were 18 to 25 years old patients $36(11.1 \%)$ and $35(3.7 \%)$ tooth were most commonly underwent indirect restoration on disto occlusal aspect, in 26 to 40 years $36(18.5 \%), 25(7.4 \%), 46(25.9 \%)$ mostly underwent indirect restoration on disto occlusal aspect. And in 41 to 61 years old patient 16 (3.7\%), 27 (7.4\%), $46(11.1 \%)$, $35(3.7 \%), 45(7.4 \%)$ mostly underwent indirect restoration on disto occlusal aspect.

Figure 3 shows the association of gender and tooth number of patients who underwent indirect restoration on disto occlusal aspect were in males 46 (25.9\%), 36(22.2\%), 27,25,35,45 (7.4\%), $16(3.7 \%)$ tooth underwent indirect restoration on disto occlusal aspect.In females 36(7.4\%),46(11.1\%)tooth underwent indirect restoration on disto occlusal aspect. Indirect restoration on disto occlusal aspect was most common in males than females $(81.4 \%$ vs $18.5 \%)$.

Figure 1. Bar chart represents the association between different age groups and gender of patients who underwent indirect restoration on disto occlusal aspect. $\mathrm{X}$ axis represents different age groups and $\mathrm{Y}$ axis represents the number of patients.

Majority were Males (green) in the age group between 26-40 year.[Chi square value-0.517 and $p$ value -0.772 ( $p>0.05$ )] $\mathrm{show}$ ing there is no statistically significant difference between the age and gender.

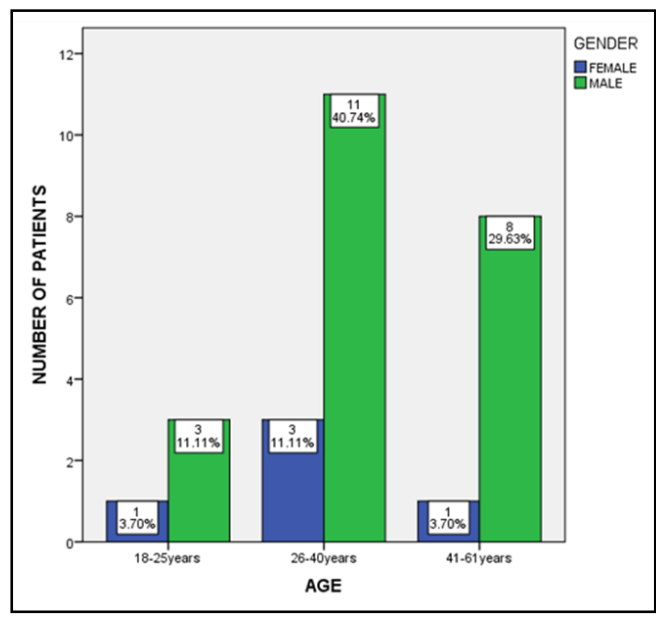


Figure 2. Bar chart represents the association of age and tooth number of patients who underwent indirect restoration on disto occlusal aspect. $\mathrm{X}$ axis represents different tooth numbers and $\mathrm{Y}$ axis represents the age of patients. Majority of patients were between the age group of $26-40$ years(green) . [chi square test value - 22.503;p value -0.032 ( $p<0.05$ )] implying that there is statistically significant difference between the age group and tooth number.

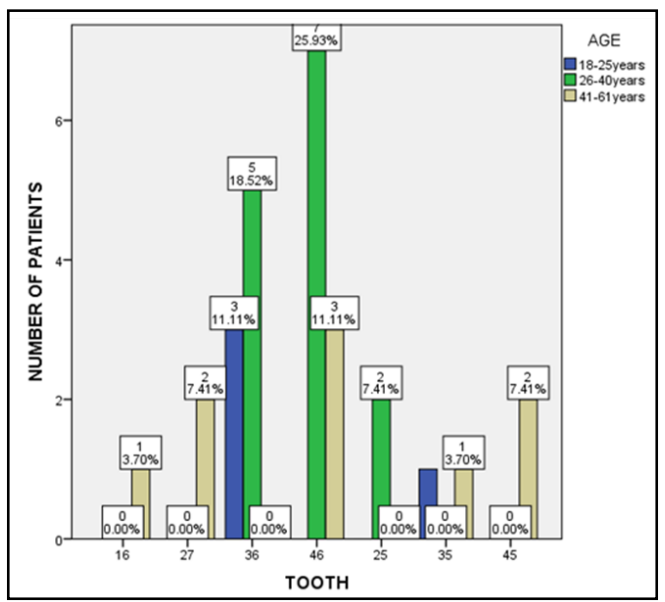

Figure 3. Bar chart represents the association of gender and tooth number of patients who underwent indirect restoration on disto occlusal aspect. $\mathrm{X}$ axis represents the gender and $\mathrm{Y}$ axis represents the number of female (blue) and male patients(green). Majority of male patients had indirect restoration on disto occlusal aspect.[Chi square value 3.142 and $p$ value- $0.791(\mathrm{p}>0.05)$ ] implying that there is no significant difference between the gender and tooth number.

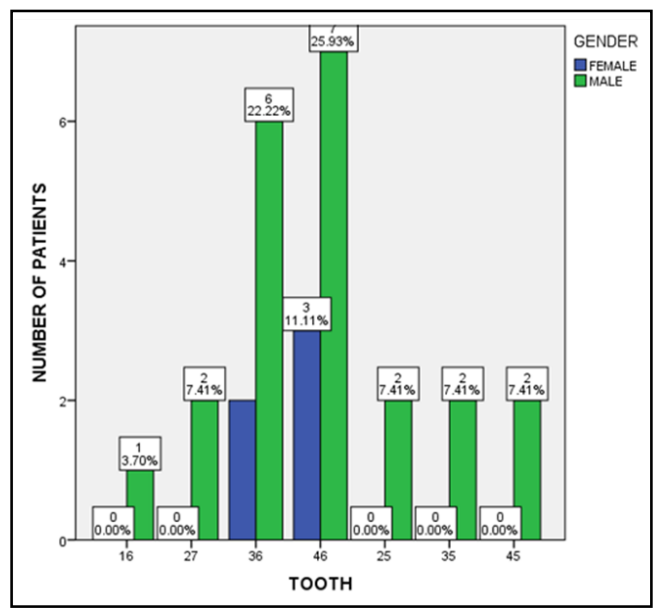

Table 1. Shows association of age and gender of patients who underwent indirect restoration on disto occlusal aspect. Majority of Males $40.7 \%$ in the age group between 26-40 year [Chi square value-0.517 and $p$ value $-0.772(p>0.05)$ ] 3 howing there is no statistically significant difference.

\begin{tabular}{|c|c|c|c|c|c|}
\hline AGE & FEMALE & MALE & TOTAL & Chi-square value & P value \\
\hline $\begin{array}{c}\text { 18-25 } \\
\text { YEARS }\end{array}$ & 1 & 3 & 4 & & \\
\cline { 1 - 4 } $\begin{array}{c}26-40 \\
\text { YEARS }\end{array}$ & 3 & 11 & 14 & 0.517 & 0.772 \\
\cline { 1 - 3 } $\begin{array}{c}41-61 \\
\text { YEARS }\end{array}$ & 1 & 8 & 9 & & \\
\cline { 1 - 3 } TOTAL & 5 & 22 & 27 & & \\
\hline
\end{tabular}

From the case records of 86000 patients who had visited Saveetha Dental College and Hospitals were analysed. Various studies have been reported on association between age,gender and indirect restoration on disto occlusal aspect. The results of the present study showed that the majority of male patients had indirect restoration on disto occlusal aspect. These results are in accordance with a study done by Borgia, et al on cast gold inlays in posterior tooth and he concluded that males commonly had class 2 cavities and underwent cast gold inlays [24].
Lange et al., did a study on clinical evaluation on ceramic inlays compared to composite inlays and he says that women more commonly received ceramic inlays than males. This result is not in accordance with our study however our study showed males most commonly underwent indirect restoration on disto occlusal aspect [25].

Santos et al., did a study on clinical evaluation of two types of 
ceramic inlays and onlays after 6 months and he included a study population with a mean age of 35 years and he found that molars most commonly underwent inlays than premolars. This result is in accordance with our study were the $77.7 \%$ of molars underwent indirect restoration on disto occlusal aspect [26].

Critchlow, Simon, did a study on ceramic materials have similar short-term survival rates to other materials on posterior teeth and he concluded that posterior ceramic inlays have a high survival rate [27].

Comparing the above studies, this study has almost all the posterior teeth involvement for indirect restoration on disto occlusal aspect and males most commonly indirect restoration on disto occlusal aspect. The study reports a retrospective investigation done only with the information obtained from patient reports. The present study had a smaller sample size and it was a singlecentered study and geographical limitations. Future studies may be needed to analyse the prevalence of patients who underwent indirect restoration on disto occlusal aspect and understanding its survival rates.

\section{Acknowledgement}

The study was supported by the University who provided insights and expertise that greatly assisted the study. We would also like to thank the reviewers of the article for their insights.

\section{Conclusion}

Within the limitation of the current study it was observed that there was no significance of age and gender of patients who underwent indirect restoration on disto occlusal aspect.Majority of Males in the age group between 26-40 years had indirect restoration on disto occlusal aspect. so it is important to educate patients on importance of oral hygiene maintenance especially male patients and patients aged between 26-40 years. This study emphasis on the importance of ceramic inlays which is a good treatment modality and provides a good restorative material and maintains the anatomic form, marginal integrity and has better caries resistance.

\section{References}

[1]. Hayashi M, Wilson NH, Yeung CA, Worthington HV. Systematic review of ceramic inlays. Clin. Oral Investig. 2003 Mar 1;7(1):8-19.

[2]. Kelly JR, Nishimura I, Campbell SD. Ceramics in dentistry: historical roots and current perspectives. J Prosthet Dent. 1996 Jan;75(1):18-32.Pubmed PMID: 9005250.

[3]. Fradeani M, Aquilano A, Bassein L. Longitudinal study of pressed glass-ceramic inlays for four and a half years. J Prosthet Dent. 1997 Oct;78(4):34653.Pubmed PMID: 9338865.

[4]. Banks RG. Conservative posterior ceramic restorations: a literature review. J Prosthet Dent. 1990 Jun 1;63(6):619-26.

[5]. Laverman JV. Volledig keramische restauraties [Internet]. Vol. 26, TandartsPraktijk. 2005. p. 975-80. Available from: http://dx.doi.org/10.1007/ bf03072710
[6]. Kidd EA. Microleakage in relation to amalgam and composite restorations. A laboratory study. Br Dent J. 1976 Nov 16;141(10):305-10.Pubmed PMID: 826263.

[7]. Federlin M, Thonemann B, Schmalz G. Inserts-megafillers in composite restorations: a literature review. Clin. Oral Investig. 2000 Mar 1;4(1):1-8.

[8]. George LA, Richards ND, Eichmiller FC. Reduction of marginal gaps in composite restorations by use of glass-ceramic inserts. Oper Dent. 1995 JulAug;20(4):151-4.Pubmed PMID: 8700783.

[9]. Ramamoorthi S, Nivedhitha MS, Divyanand MJ. Comparative evaluation of postoperative pain after using endodontic needle and EndoActivator during root canal irrigation: A randomised controlled trial. Aust Endod J. 2015 Aug;41(2):78-87.Pubmed PMID: 25195661.

[10]. Ramanathan S, Solete P. Cone-beam Computed Tomography Evaluation of Root Canal Preparation using Various Rotary Instruments: An in vitro Study. J Contemp Dent Pract. 2015 Nov 1;16(11):869-72.

[11]. Siddique R, Sureshbabu NM, Somasundaram J, Jacob B, Selvam D. Qualitative and quantitative analysis of precipitate formation following interaction of chlorhexidine with sodium hypochlorite, neem, and tulsi. J Conserv Dent. 2019 Jan-Feb;22(1):40-47.Pubmed PMID: 30820081.

[12]. Rajakeerthi R, Ms N. Natural Product as the Storage medium for an avulsed tooth-A Systematic Review. Cumhur. Dent. J. 2019;22(2):249-56.

[13]. Rajendran R, Kunjusankaran RN, Sandhya R, Anilkumar A, Santhosh R, Patil SR. Comparative Evaluation of Remineralizing Potential of a Paste Containing Bioactive Glass and a Topical Cream Containing Casein Phosphopeptide-Amorphous Calcium Phosphate: An in Vitro Study. Pesqui Bras Odontopediatria Clin. 2019;19:1-10.

[14]. Hussainy SN, Nasim I, Thomas T, Ranjan M. Clinical performance of resinmodified glass ionomer cement, flowable composite, and polyacid-modified resin composite in noncarious cervical lesions: One-year follow-up. J Conserv Dent. 2018 Sep-Oct;21(5):510-515.Pubmed PMID: 30294112

[15]. Kumar D, Antony S. Calcified Canal and Negotiation-A Review. Research J. Pharm. and Tech. 2018;11(8):3727-30.

[16]. Ravinthar K. Recent advancements in laminates and veneers in dentistry. Research J. Pharm. and Tech. 2018;11(2):785-7.

[17]. Noor S. Chlorhexidine: Its properties and effects. Research J. Pharm. and Tech. 2016;9(10):1755-60.

[18]. Teja KV, Ramesh S, Priya V. Regulation of matrix metalloproteinase-3 gene expression in inflammation: A molecular study. J Conserv Dent. 2018 Nov;21(6):592.

[19]. Janani K, Palanivelu A, Sandhya R. Diagnostic accuracy of dental pulse oximeter with customized sensor holder, thermal test and electric pulp test for the evaluation of pulp vitality: an in vivo study. Braz. Dent. Sci. 2020 Jan 31;23(1):8.

[20]. Jose J, Subbaiyan H. Different Treatment Modalities followed by Dental Practitioners for Ellis Class 2 Fracture-A Questionnaire-based Survey. Open Dent. J. 2020 Feb 18;14(1):59-65.

[21]. Teja KV, Ramesh S. Is a filled lateral canal-A sign of superiority?. J. Dent. Sci. 2020 Apr 2.

[22]. Manohar MP, Sharma S. A survey of the knowledge, attitude, and awareness about the principal choice of intracanal medicaments among the general dental practitioners and nonendodontic specialists. Indian J Dent Res. 2018 Nov-Dec;29(6):716-720.Pubmed PMID: 30588997.

[23]. Nandakumar M, Nasim I. Comparative evaluation of grape seed and cranberry extracts in preventing enamel erosion: An optical emission spectrometric analysis. J Conserv Dent. 2018 Sep-Oct;21(5):516-520.Pubmed PMID: 30294113.

[24]. Borgia E, Barón R, Borgia JL. Estudio clínico retrospectivo, de 656 restauraciones de oro colado en dientes posteriores, entre 5 y 44 años: Análisis de los resultados. Odontoestomatología. 2018 Jun;20(31):16-26.

[25]. Lange RT, Pfeiffer P. Clinical evaluation of ceramic inlays compared to composite restorations. Oper Dent. 2009 May-Jun;34(3):263-72.Pubmed PMID: 19544814

[26]. Santos MJ, Francischone CE, Santos Júnior GC, Bresciani E, Romanini JC, Saqueto R, et al. Clinical evaluation of two types of ceramic inlays and onlays after 6 months. J Appl Oral Sci. 2004 Sep;12(3):213-8.Pubmed PMID: 21049255.

[27]. Critchlow S. Ceramic materials have similar short term survival rates to other materials on posterior teeth. Evid Based Dent. 2012 Jun;13(2):49. Pubmed PMID: 22722415. 